\title{
CHANGES IN THE CONTENT OF SOME MACRONUTRIENTS IN BASIL HERBAGE INDUCED BY DIFFERENT NITROGEN AND POTASSIUM FERTILIZATION RATES*
}

\author{
Renata Nurzyńska-Wierdak ${ }^{\mathbf{1}}$, Ewa Rożek ${ }^{\mathbf{1}}$, \\ Bartłomiej Borowski ${ }^{1}$, Katarzyna Dzida ${ }^{2}$, \\ Zbigniew Jarosz ${ }^{2}$ \\ ${ }^{1}$ Chair of Vegetable Crops and Medicinal Plants \\ ${ }^{2}$ Chair of Soil Cultivation and Fertilization of Horticultural Plants \\ University of Life Science in Lublin
}

\begin{abstract}
This experiment, carried out in a greenhouse from February to May in 2008-2010, was designed to determine the effect of an increased rate of nitrogen and potassium on the content of phosphorus, calcium, magnesium, chlorine and sulphur in basil herbage as well as to trace relationships between a basil cultivar and changes in the mineral composition of the herbage as influenced by the applied rates of nutrients. The mineral composition of basil herbage was determined on the basis of an analysis of the growing substrate conducted after the harvest of the experimental plants. Two Polish cultivars of basil, called Kasia and Wala, as well as a green-leaved form popular on the domestic horticultural market, were grown from seedlings in pots $\left(4 \mathrm{dm}^{3}\right)$ filled with sphagnum peat of the $\mathrm{pH}$ between 5.5-6.0. The following amounts of nutrients were applied, expressed in $\mathrm{g}$ per $1 \mathrm{dm}^{3}$ of the growing substrate: $0.2,0.4,0.6,0.9 \mathrm{~N}$ in the form of ammonium nitrate; $0.4,0.8 \mathrm{~K}$ in the form of potassium sulphate; $0.4 \mathrm{P}$ as $20 \% \mathrm{P}$ superphosphate; $0.3 \mathrm{Mg}$ in the form of magnesium sulphate monohydrate, as well as the following micronutrients (in $\mathrm{g}$ per $1 \mathrm{dm}^{3}$ of the growing substrate): $8.0 \mathrm{Fe}(\mathrm{EDTA}), 5.1 \mathrm{Mn}\left(\mathrm{MnSO}_{4} \cdot \mathrm{H}_{2} \mathrm{O}\right), 13.3 \mathrm{Cu}\left(\mathrm{CuSO}_{4} \cdot 5 \mathrm{H}_{2} \mathrm{O}\right)$, $0.74 \mathrm{Zn}\left(\mathrm{ZNSO}_{4} \cdot 7 \mathrm{H}_{2} \mathrm{O}\right)$, $1.6 \mathrm{~B}\left(\mathrm{H}_{3} \mathrm{BO}_{3}\right)$ and $\left.3.7 \mathrm{Mo}\left(\left(\mathrm{NH}_{4}\right)_{6} \mathrm{Mo}_{7}\right)_{24} \cdot 4 \mathrm{H}_{2} \mathrm{O}\right)$.

The plants were harvested at the beginning of flowering (29 May 2008, 25 May 2009 and 27 May 2010) by cutting off the aerial part of the stem above its lignified parts. The herbage was dried at $70^{\circ} \mathrm{C}$, ground and used for chemical analysis. The analysed basil herbage proved to be a good source of phosphorus, calcium, chlorine and sulphur. The increasing
\end{abstract}

dr hab. Renata Nurzyńska-Wierdak, Chair of Vegetable Crops and Medicinal Plants, University of Life Science in Lublin, Leszczyńskiego 58, 20-068 Lublin, Poland, e-mail: renata.nurzynska@up.lublin.pl

*Research financed by Ministry of Science and Higher Education under project No N N310 450738. 
rate of nitrogen resulted in an increased concentration of the mineral nutrients determined in the basil herbage. The magnesium concentration in the basil herbage dry matter was not dependent on a cultivar and nitrogen rate, but increased under the influence of the higher amount of potassium applied. On the other hand, the raised amounts of potassium did not modify the concentrations of phosphorus and sulphur in the examined plant material.

Key words: Ocimum basilicum L., cultivar, nitrogen and potassium fertilization.

\title{
ZMIANY ZAWARTOŚCI NIEKTÓRYCH MAKROELEMENTÓW W ZIELU BAZYLII POD WPŁYWEM ZRÓŻNICOWANEGO ŻYWIENIA ROŚLIN AZOTEM I POTASEM
}

\begin{abstract}
Abstrakt
Celem doświadczenia przeprowadzonego w okresie od lutego do maja 2008-2010 w szklarni było określenie wpływu zwiększonej dawki azotu oraz potasu na zawartość fosforu, wapnia, magnezu, chloru i siarki w zielu bazylii oraz prześledzenie zależności między odmiana bazylii a zmianami składu mineralnego ziela pod wpływem zastosowanych dawek składników pokarmowych. Analizę składu mineralnego ziela bazylii oparto na analizie podłoża po zbiorze roślin doświadczalnych. Bazylię dwóch polskich odmian Kasia i Wala oraz formy zielonolistnej, popularnej na krajowym rynku ogrodniczym, uprawiano $\mathrm{z}$ rozsady w doniczkach $\left(4 \mathrm{dm}^{3}\right)$, wypełnionych torfem sfagnowym o pH 5,5-6,0. Zastosowano następujące ilości składników pokarmowych ( $\mathrm{g} \mathrm{dm}^{-3}$ podłoża): 0,$2 ; 0,4 ; 0,6 ; 0,9 \mathrm{~N} \mathrm{w}$ formie saletry amonowej; 0,$4 ; 0,8 \mathrm{~K}$ w postaci siarczanu potasu; $0,4 \mathrm{P}$ w postaci superfosfatu $20 \% \mathrm{P}$; $0,3 \mathrm{Mg} \mathrm{w}$ formie jednowodnego siarczanu magnezu oraz mikroelementy (mg $1 \mathrm{dm}^{-3}$ podłoża) 8,0 Fe (EDTA); 5,1 $\mathrm{Mn}\left(\mathrm{MnSO}_{4} \cdot \mathrm{H}_{2} 0\right] ; 13,3 \mathrm{Cu}\left(\mathrm{CuSO}_{4} \cdot 5 \mathrm{H}_{2} \mathrm{O}\right) ; 0,74 \mathrm{Zn}\left(\mathrm{ZNSO}_{4} \cdot 7 \mathrm{H}_{2} \mathrm{O}\right)$; $1,6 \mathrm{~B}\left(\mathrm{H}_{3} \mathrm{BO}_{3}\right)$ i $\left.3,7 \mathrm{Mo}\left(\left(\mathrm{NH}_{4}\right)_{6} \mathrm{Mo}_{7}\right)_{24} \cdot 4 \mathrm{H}_{2} \mathrm{O}\right)$.

Zbiór roślin przeprowadzono na początku kwitnienia (29 maja 2008, 25 maja 2009 i 27 maja 2010), ścinając nadziemną część pędu powyżej jej zdrewniałych fragmentów. Ziele wysuszono w temp. $70^{\circ} \mathrm{C}$, zmielono i przeznaczono do analiz chemicznych. Badane ziele bazylii okazało się dobrym źródłem fosforu, wapnia, chloru i siarki. Wzrastająca dawka azotu powodowała zwiększenie koncentracji badanych składników mineralnych w roślinie. Koncentracja magnezu w suchej masie ziela bazylii nie była uzależniona od odmiany oraz dawki azotu, natomiast zwiększała się pod wpływem wzrastającej ilości potasu. Zwiększona ilość potasu nie modyfikowała udziału fosforu i siarki w badanym materiale roślinnym.
\end{abstract}

Słowa kluczowe: Ocimum basilicum L., odmiana, nawożenie azotem i potasem.

\section{INTRODUCTION}

The nutritional status of plants affects yield amount and quality as well as plant resistance to stress factors. An optimal supply of macro- and micronutrients to cultivated plants, provided that light, thermal and moisture conditions are adequate, ensures high quality yield, reduces production costs and restrains the risk of environmental contamination. Herbal plants constitute valuable raw material, whose biological activity depends on the content of the major biologically active substances and accompanying macroand micronutrients, enzymes, and vitamins. Nitrogen and potassium belong to the most important nutrients taken up by plants in the largest quanti- 
ties. Nitrogen, which is called a yield-stimulating nutrient, affects both volumes of yields and the chemical composition of yield components (CHEN et al. 2004, NurzyŃsKa-Wierdak 2006, Biesiada, KoŁota 2010, Biesiada, Kú́ 2010). The primary function of nitrogen is to participate in the formation of amino acids, which are structural elements of proteins as well as pyrimidine and purine bases, nucleotides and nucleic acids (BAHMANYAR, SOODAEE-MASHAEE 2010). As a component of these and other compounds, nitrogen participates in almost all biochemical reactions occurring in living organisms. Nitrogen uptake by plants is associated with the presence of other important mineral nutrients in the nutritional environment, including potassium. Disturbances in nitrogen metabolism, arising from potassium deficiency, manifest themselves in changes in the proportions between nitrogen fractions as well as in the accumulation of harmful amino substances in plants, such as agmatine, N-carbamoyl putrescine, putrescine or ammonium ions (NowACKI 1980). The application of increased potassium fertilization has a clear effect on the decrease in the concentration of nitrates (HANAFY-AHMED et al. 2000, MichAŁOJĆ 2000, NURZYŃSKA-WIERDAK 2006).

Basil responds very well to fertilization, especially organic one, and can thoroughly use up nutrients (Sifola, BARBIERI 2006, ZhelJAZKov et al. 2008, SEIDLER-ŁoŻYKOWSKA et al. 2009, NURZYŃSKA-WIERDAK et al. 2011). Increased rates of nitrogen, potassium, phosphorus, sulphur and calcium modify the mineral composition of basil herbage (Yamamoto, TAKano 1996, RaO et al. 2007, GEetha et al. 2009, BiESIADA, Kús 2010, DzIDA 2010). Furthermore, foliar feeding stimulates the height and weight of basil plants and raises the concentration of potassium and calcium in basil herbage (NURZYŃSKA-WIERDAK, BOROWSKI 2011, NURZYŃSKA-WIERDAK et al. 2011). Calcium, phosphorus, magnesium, and sulphur, i.e. the minerals that are the major building material for bones, teeth, skin and hair, play an important physiological function in the human organism; in addition to dairy products, raw plants are a source of these mineral components (FRIEDRICH 2002). In turn, chlorine is important for the water and electrolyte management as well as for the acidic and alkaline balance. Magnesium, a poorly absorbable ion, seems to be particularly important; its deficiency raises our sensitivity to stress, which is an underlying cause of many civilization diseases (KŁOSIEWICZ-LaTOSZEK 1993). The factors inhibiting magnesium bioavailability in the alimentary canal include, inter alia, high-protein and high-fat diet as well as foreign substances in food and addictive substances (FRIEDRICH 2002). Herbal raw materials, which are used as seasoning, therapeutic and aromatic agents, can be a valuable, although still underappreciated, source of macro- and micronutrients. The aim of the present study was to determine the effect of an increased rate of nitrogen and potassium on the content of phosphorus, calcium, magnesium, chlorine and sulphur in basil herbage as well as to trace relationships between a basil cultivar and changes in the mineral composition of the herb as influenced by the applied rates of nutrients. The mineral composition of basil herbage was determined on the basis of an analysis of the growing substrate conducted after the harvest of the experimental plants. 


\section{MATERIAL AND METHODS}

The present experiment was conducted in a detached greenhouse, with the north-south orientation of the major axis. The greenhouse belonged to the Department of Vegetable Crops and Medicinal Plants, University of Life Sciences in Lublin. The experiment was conducted from February to May in $2008-2010$. The temperature in the greenhouse was at $18-25^{\circ} \mathrm{C}$ during the day and $12-15^{\circ} \mathrm{C}$ at night. Two Polish cultivars of basil, Kasia and Wala (breeder and distributor: Institute of Natural Fibres and Medicinal Plants in Poznań) as well as a green-leaved form popular on the domestic horticultural market (distributor: a seed production company called PNOS Ożarów Mazowiecki), were grown from seedlings. The plants were grown in pots $\left(4 \mathrm{dm}^{3}\right)$ filled with sphagnum peat of the $\mathrm{pH}$ between 5.5-6.0. The experiment was conducted using a completely randomized design with 8 replicates. A single basil plant, i.e. an experimental unit, grew in each pot. Basil seeds were sown on the following dates: 28 February (2008), 12 March (2009), and 3 March (2010). Before sowing, seeds were dressed with the fungicide Dithane Neo Tec 75 WG. Emergence occurred after about 8 days. After 18-20 days from sowing, the plants were transferred into multi-cell trays filled with peat substrate. The present study was carried out under strictly controlled conditions. No presence of diseases or pests was found on the plants during the growing period, therefore no chemical protection was used. The plants were transplanted to pots about 25 days after sowing, at the 4 trueleaf stage.

The following amounts of nutrients (in $\mathrm{g}$ per $1 \mathrm{dm}^{3}$ of growing substrate) were applied in the experiment: $0.2,0.4,0.6,0.9 \mathrm{~N}$ in the form of ammonium nitrate; $0.4,0.8 \mathrm{~K}$ in the form of potassium sulphate; $0.4 \mathrm{P}$ as $20 \% \mathrm{P}$ superphosphate; $0.3 \mathrm{Mg}$ in the form of magnesium sulphate monohydrate, and the following micronutrients (in $\mathrm{g}$ per $1 \mathrm{dm}^{3}$ of growing substrate): $8.0 \mathrm{Fe}$ (EDTA), $5.1 \mathrm{Mn}\left(\mathrm{MnSO}_{4} \cdot \mathrm{H}_{2} \mathrm{O}\right), 13.3 \mathrm{Cu}\left(\mathrm{CuSO}_{4} \cdot 5 \mathrm{H}_{2} \mathrm{O}\right), 0.74 \mathrm{Zn}$ $\left(\mathrm{ZNSO}_{4} \cdot 7 \mathrm{H}_{2} \mathrm{O}\right), 1.6 \mathrm{~B}\left(\mathrm{H}_{3} \mathrm{BO}_{3}\right)$, and $\left.3.7 \mathrm{Mo}\left[\left(\mathrm{NH}_{4}\right)_{6} \mathrm{Mo}_{7}\right)_{24} \cdot 4 \mathrm{H}_{2} \mathrm{O}\right]$. During the experiment, the plants were watered with the same amount of water (250-300 ml) every 1-2 days. The plants were harvested at the beginning of flowering (29 May 2008, 25 May 2009, and 27 May 2010) by cutting off the aerial portion of the stem above its lignified parts. The herbage was dried at $70^{\circ} \mathrm{C}$, ground and the following were determined in $2 \% \mathrm{CH}_{3} \mathrm{COOH}$ extract: chlorine (colourimetrically with $\mathrm{AgNO}_{3}$ ) and sulphates with $\mathrm{BaCL}_{2}$. After dry combustion at $550^{\circ} \mathrm{C}$, phosphorus was determined colourimetrically with ammonium vanadium and molybdate, while potassium, calcium, and magnesium were determined with the atomic absorption method using a Perkin-Elmer Analyst 300 spectrometer.

Immediately after plant harvest, samples of the growing substrate were taken for chemical analysis and the following were determined in the substrate: in $0.03 \mathrm{M}$ acetic acid extract, the content of phosphorus, calcium, 
magnesium, chlorine and sulphates using the same method as applied for the plant material, substrate's $\mathrm{pH}$ - potentiometrically in $\mathrm{H}_{2} \mathrm{O}$, and ion concentration (EC) - conductometrically. The results of chemical assays were statistically described using analysis of variance for three-way cross-classification, evaluating the significance of differences with Tukey's confidence intervals and performing LSD calculations at the level of significance $\alpha=0.05$.

\section{RESULTS AND DISCUSSION}

The herbage of the basil cultivars differed significantly in the content of the macronutrients, except for magnesium (Table 1). The cultivar Kasia was characterized by the highest concentration of phosphorus and calcium, while the green-leaved form accumulated the highest amount of chlorine and sulphur. These results are in agreement with those obtained by DzIDA (2010), who confirms cultivar-specific differences in this respect. The mineral composition of the investigated herbal material was generally comparable to the literature data (KHALID 2006, RAO et al. 2007, SEIDLER-ŁoŻYKowSKA et al. 2009, Biesiada, Kuś 2010, Dzida 2010). The biggest differences appeared in the proportion of phosphorus (RAO et al. 2007, DZIDA 2010), calcium and magnesium (SEIDler-ŁoŻYKowsKa et al. 2009, DzidA, 2010), and were probably induced by different amounts of mineral nutrients in the nutritional environment of the cultivated plants as well as cultivar-specific differences. The growth dynamics of basil plants, like their morphological characteristics, is highly varied (LABRA et al. 2004, NURZYŃSKA-WIERDAK 2007, ABDUELRAHMAN et al. 2009, Svecova, Neugebauerova 2010). The leaf/stem ratio (LS) and the leaf area index (LAI) in basil are significantly affected by both a nitrogen rate (LAI) and a cultivar (LS and LAI) (Sifola, BARBIERI 2006), which should also be attributable to the plant's mineral balance.

The applied nitrogen rate significantly modified the concentrations of phosphorus, magnesium, chlorine and sulphur in the basil plants (Table 1). The study showed that the concentrations of the these macronutrients in the basil herbage increased with the increasing rate of nitrogen; phosphorus was an exception, since it increased only in the series from the lowest to the second highest rate of nitrogen. The level of macronutrients in the basil herbage depends on the rate of nitrogen and irrigation (BIESIADA, Kuś 2010). These relationships partly arise from the yield-stimulating role of nitrogen and from the interactions between macronutrients. It should be noted here that the analysis of the growing substrate after plant harvest did not confirm the significant effect of the nitrogen rate on its chemical composition, which should be attributable to the uptake of minerals by the plants during their growth (Table 2). The concentration of phosphorus, which is always taken up by plants against its concentration gradient, was the highest in the analyzed basil herbage under the substrate rate of nitrogen, but de- 
Table 1

Phosphorus, calcium, magnesium, chlorine and sulphur content in sweet basil herbage (mean for 2008-2010)

\begin{tabular}{|c|c|c|c|c|c|c|c|}
\hline \multirow{2}{*}{$\begin{array}{l}\text { Cultivar } \\
\text { (A) }\end{array}$} & $\mathrm{N}$ dose (B) & $\mathrm{K}$ dose $(\mathrm{C})$ & $\mathrm{P}$ & $\mathrm{Ca}$ & $\mathrm{Mg}$ & $\mathrm{Cl}$ & $\mathrm{S}-\mathrm{SO}_{4}$ \\
\hline & \multicolumn{2}{|c|}{$\left(\mathrm{g} \mathrm{dm}^{-3}\right)$} & \multicolumn{5}{|c|}{ (\% d.m.) } \\
\hline \multirow{8}{*}{ Kasia } & \multirow{2}{*}{0.2} & 0.4 & 0.69 & 1.54 & 0.20 & 0.24 & 0.18 \\
\hline & & 0.8 & 0.59 & 1.52 & 0.22 & 0.53 & 0.24 \\
\hline & \multirow{2}{*}{0.4} & 0.4 & 0.71 & 1.64 & 0.22 & 0.62 & 0.22 \\
\hline & & 0.8 & 0.77 & 1.56 & 0.25 & 0.65 & 0.23 \\
\hline & \multirow{2}{*}{0.6} & 0.4 & 0.72 & 1.69 & 0.27 & 0.62 & 0.23 \\
\hline & & 0.8 & 0.76 & 1.69 & 0.28 & 0.64 & 0.24 \\
\hline & \multirow{2}{*}{0.9} & 0.4 & 0.63 & 1.95 & 0.30 & 0.86 & 0.23 \\
\hline & & 0.8 & 0.71 & 1.62 & 0.34 & 0.98 & 0.23 \\
\hline \multicolumn{3}{|l|}{ Mean (A) } & 0.69 & 1.65 & 0.26 & 0.64 & 0.22 \\
\hline \multirow{8}{*}{ Wala } & \multirow{2}{*}{0.2} & 0.4 & 0.59 & 1.33 & 0.16 & 0.79 & 0.24 \\
\hline & & 0.8 & 0.48 & 1.23 & 0.18 & 0.52 & 0.28 \\
\hline & \multirow{2}{*}{0.4} & 0.4 & 0.64 & 1.45 & 0.21 & 0.47 & 0.28 \\
\hline & & 0.8 & 0.61 & 1.30 & 0.23 & 0.66 & 0.29 \\
\hline & \multirow{2}{*}{0.6} & 0.4 & 0.58 & 1.55 & 0.24 & 0.47 & 0.32 \\
\hline & & 0.8 & 0.55 & 1.26 & 0.26 & 0.60 & 0.34 \\
\hline & \multirow{2}{*}{0.9} & 0.4 & 0.63 & 1.61 & 0.27 & 1.14 & 0.28 \\
\hline & & 0.8 & 0.53 & 1.25 & 0.31 & 1.20 & 0.31 \\
\hline \multicolumn{3}{|l|}{ Mean (A) } & 0.58 & 1.37 & 0.23 & 0.69 & 0.27 \\
\hline \multirow{8}{*}{ Green } & \multirow{2}{*}{0.2} & 0.4 & 0.54 & 1.41 & 0.16 & 0.46 & 0.28 \\
\hline & & 0.8 & 0.54 & 1.23 & 0.18 & 0.64 & 0.31 \\
\hline & \multirow{2}{*}{0.4} & 0.4 & 0.62 & 1.59 & 0.21 & 0.59 & 0.31 \\
\hline & & 0.8 & 0.59 & 1.47 & 0.23 & 0.73 & 0.32 \\
\hline & \multirow{2}{*}{0.6} & 0.4 & 0.82 & 1.64 & 0.24 & 0.75 & 0.34 \\
\hline & & 0.8 & 0.69 & 1.55 & 0.26 & 0.72 & 0.37 \\
\hline & \multirow{2}{*}{0.9} & 0.4 & 0.80 & 1.96 & 0.27 & 1.44 & 0.34 \\
\hline & & 0.8 & 0.72 & 1.41 & 0.31 & 1.64 & 0.40 \\
\hline \multicolumn{3}{|l|}{ Mean (A) } & 0.66 & 1.53 & 0.25 & 0.87 & 0.33 \\
\hline \multirow{4}{*}{ Nean (B) } & \multicolumn{2}{|l|}{0.2} & 0.57 & 1.38 & 0.19 & 0.48 & 0.24 \\
\hline & \multicolumn{2}{|l|}{0.4} & 0.66 & 1.50 & 0.23 & 0.62 & 0.27 \\
\hline & \multicolumn{2}{|l|}{0.6} & 0.68 & 1.56 & 0.26 & 0.63 & 0.29 \\
\hline & 0.9 & & 0.67 & 1.63 & 0.30 & 1.21 & 0.31 \\
\hline Mean (C) & 0.4 & & 0.66 & 1.61 & 0.23 & 0.68 & 0.27 \\
\hline (1) & 0.8 & & 0.63 & 1.42 & 0.26 & 0.79 & 0.29 \\
\hline Mean & & & 0.64 & 1.52 & 0.25 & 0.73 & 0.28 \\
\hline $\mathrm{LSD}_{0.05}$ & & & 0.10 & 0.23 & n. s. & 0.10 & 0.03 \\
\hline $\begin{array}{l}\mathrm{A} \\
\mathrm{B}\end{array}$ & & & 0.13 & 0.11 & 0.05 & 0.12 & 0.04 \\
\hline C & & & n. s. & 0.15 & n. s. & 0.06 & n. s. \\
\hline $\mathrm{AxB}$ & & & n. s. & n. s. & n. s. & 0.28 & n. s. \\
\hline
\end{tabular}

n.s. - not significance 
creased under a higher dose of nitrogen; at the same time, this mineral remained in the substrate in a larger amount. Given the fact that only some of phosphates introduced into the nutritional environment are used by plants during the same growing season, the above relationship is a logical consequence of mineral nutrition of plants. The phosphorus content determined in the basil herbage was comparable to the results reported by other authors (ÖZCAN 2004, ÖzCAN et al. 2005, 2007). The calcium content in the investigated herbage averaged $1.52 \%$ of dry weight (DW) and it was lower than in some other described basil plants (ÖzCAN 2004, SEIDLER-ŁoŻYKowsKa et al. 2009, Biesiada, Kuś 2010, Dzida 2010), which could have resulted from cultivar-specific differences and from the level of nutrients in soil, in particular under increased calcium fertilization (DzIDA 2010). The concentration of the above nutrient increased under the influence of the increasing rate of nitrogen, but the differences in the calcium content in plants fertilized with the substrate rates of nitrogen were not statistically significant. The magnesium concentration in the investigated plant material was on average $0.25 \%$ DW, being much lower than determined by ÖzCAN (2004), but was higher under the increasing rate of nitrogen. Similar relationships were shown by BIESIADA and Kuś (2010) in the cultivation of a red-leaved form of basil. Excessively high levels of $\mathrm{NH}_{4}{ }^{+}$and $\mathrm{K}^{+}$ions in the nutritional environment reduce magnesium uptake by plants. Good supply of magnesium to the analyzed basil plants can be explained by the adequate concentration of ions in the substrate and its optimal $\mathrm{pH}$. The concentrations of chlorine and sulphur in the investigated basil herbage increased with the increasing rate of nitrogen (Table 1). These relationships should be attributable to the increase in the basil plant biomass under the increasing rate of nitrogen (NURZYŃSKA-WIERDAK et al. 2012) rather than to the correlation between the ions.

The mineral composition of the investigated basil herb was affected by the potassium rate, but significant differences were shown only for the concentration of calcium and chlorine (Table 1). The increased concentration of potassium in the nutritional environment of the plants caused a decrease in calcium in the basil herbage dry matter, most probably due to the antagonism between these two mineral nutrients. In turn, the chlorine concentration significantly increased under the influence of the increasing rate of potassium. Different concentrations of elements in the plant, as compared to their concentration in the nutritional environment, indicate selective, active uptake of elements, frequently against their concentration gradient in the plant. Moreover, the accumulation of macronutrients by the plant under the increased mineral fertilization occurred at different intensity in particular plant organs (Ali et al. 2003, Dzida 2010, Shehu et al. 2010, Markiewicz et al. 2011).

The growing substrate after the harvest of the basil plants was characterized by a pH in the range of 4.50-6.10 and an ion concentration (EC) of 1.3-2.3 $\mathrm{mS} \mathrm{cm} \mathrm{cm}^{-1}$, depending on the rate of nitrogen and potassium (Table 2). 
Table 2

$\mathrm{pH}$ values and EC in substrate after sweet basil harvest (2008-2010)

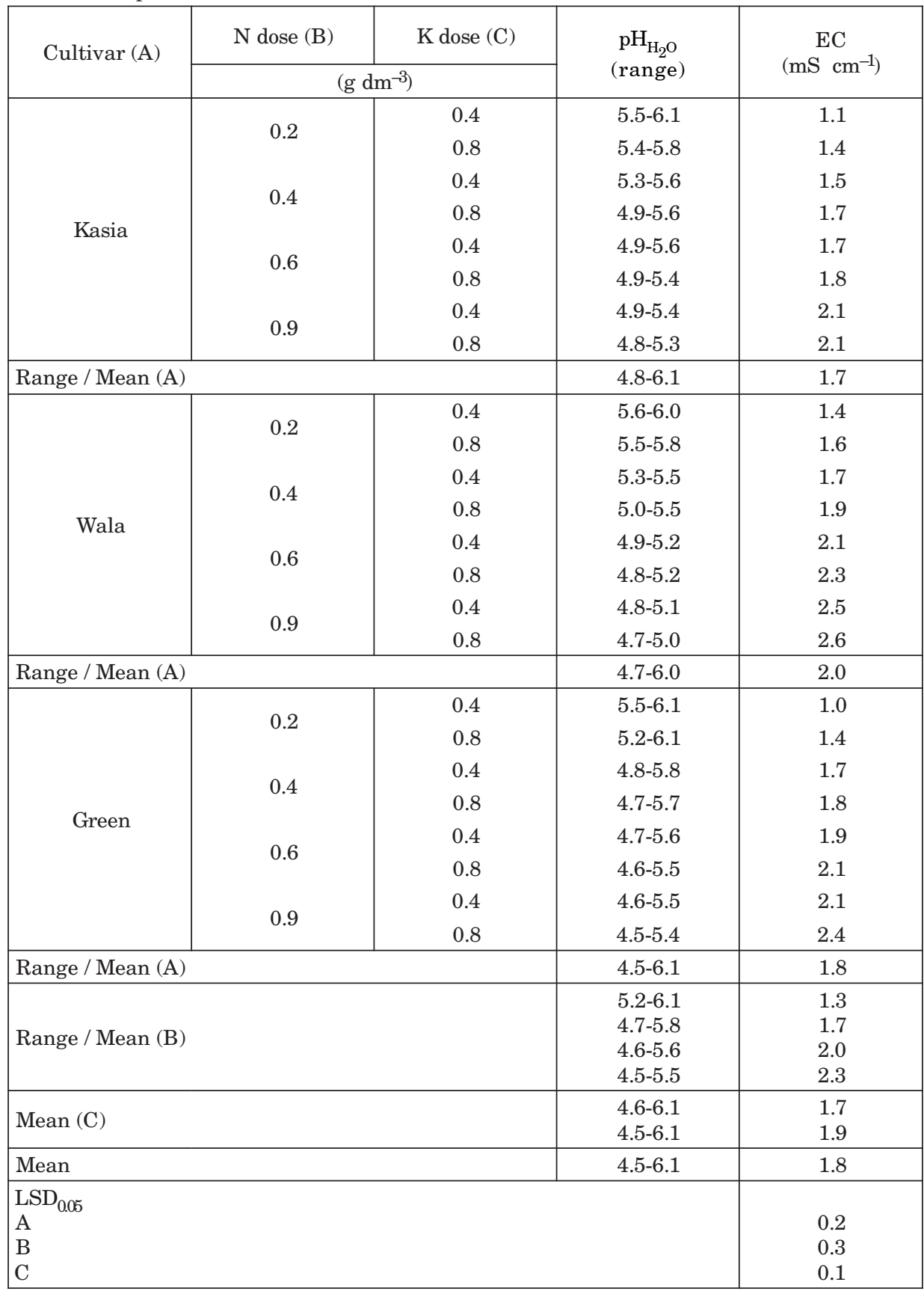

n.s. - not significance 
The substrate on which the basil cultivars were grown differed in terms of the value of both $\mathrm{pH}$ and $\mathrm{EC}$, which could indicate different nutritional requirements of the cultivars, associated even with a different growth dynamics (NURZYŃSKA-WIERDAK et al. 2011). On the other hand, the analysis of the nutrient content in the substrate does not confirm this hypothesis (Table 3). Residues of the macronutrients in the substrate show that the basil plants took up nutrients in a similar way and that nutrient availability was adequate. It was only in the case of calcium that significantly more of this element remained in the substrate used for growing the green-leaved basil form than in the other substrates, which could suggest its more intensive uptake. These differences have also been shown for other basil cultivars (DzIDA 2010), but these relationships could have also been caused by the increased rate of calcium carbonate applied in the nutrition of plants. The increased level of nitrogen and potassium caused an increase in the value of the substrate's EC (Table 2). Similar correlations have been shown in other papers (Dzida 2004, Dzida, Pitura 2008, Golcz et al. 2008, NurZyísKa-WierdaK 2006, 2009), but more importance in this respect is generally attached to nitrate ions than to potassium ions. The applied rates of nitrogen and potassium did not have a significant effect on the content of phosphorus, calcium, magnesium and chlorine in the substrate after plant harvest. However, it was shown that the quantity of sulphates in the substrate increased with the increasing rate of potassium. $\mathrm{SO}_{4}{ }^{2-}$ ion uptake is not inhibited by nitrates, phosphates or chlorides, but only by selenate anions, hence the above relationships should not be linked to the competition between ions, in particular given that the plants receiving more potassium also accumulated more sulphur in the herbage, but this was not statistically confirmed (Table 1). Similar correlations have been shown in our earlier papers (NuRZYŃSKA-WIERDAK 2006, 2009) and they should be attributable to the type of fertilizer applied, which was potassium sulphate. When comparing the mineral composition of the plants and of the substrate on which they were grown to the concentration of salts in the substrate, the present study demonstrated that the uptake and absorption of phosphorus, calcium, magnesium, chlorine and sulphur by basil plants were not reduced at the increasing value of EC. Excessive salt concentration in the substrate results in a reduction in N, P, $\mathrm{Ca}$ and $\mathrm{Mg}$ uptake and increased concentration of $\mathrm{Na}$ and $\mathrm{Cl}$ in plant tissues (Esmaili et al. 2008). On the other hand, however, differences in nutrient uptake by plants also arise from their cultivation on different substrates. Furthermore, nitrogen fertilization increases plant tolerance to excessive salinity through an improvement in their nutritional status (Esmalli et al. 2008). The results obtained in this study indicate that basil plants received adequate nitrogen and potassium fertilization, which enabled their proper nutrient uptake and absorption, also under the increasing concentration of salts in the growing substrate. 
Table 3

Phosphorus, calcium, magnesium, chlorine and sulphur content

in a substrate from sweet basil cultivation (mean for 2008-2010)

\begin{tabular}{|c|c|c|c|c|c|c|c|}
\hline \multirow{2}{*}{$\begin{array}{l}\text { Cultivar } \\
\text { (A) }\end{array}$} & $\mathrm{N}$ dose $(\mathrm{B})$ & $\mathrm{K}$ dose $(\mathrm{C})$ & $\mathrm{P}$ & $\mathrm{Ca}$ & $\mathrm{Mg}$ & $\mathrm{Cl}$ & $\mathrm{S}-\mathrm{SO}_{4}$ \\
\hline & \multicolumn{2}{|c|}{$\left(\mathrm{g} \mathrm{dm}^{-3}\right)$} & \multicolumn{5}{|c|}{$\left(\mathrm{mg}\right.$ d.m. $\left.{ }^{-3}\right)$} \\
\hline \multirow{8}{*}{ Kasia } & \multirow{2}{*}{0.2} & 0.4 & 162.3 & 1800.0 & 206.3 & 182.5 & 360.7 \\
\hline & & 0.8 & 174.2 & 1765.3 & 174.3 & 160.3 & 405.8 \\
\hline & \multirow{2}{*}{0.4} & 0.4 & 165.8 & 1734.3 & 171.0 & 174.2 & 321.2 \\
\hline & & 0.8 & 251.8 & 1496.7 & 176.3 & 187.7 & 412.3 \\
\hline & \multirow{2}{*}{0.6} & 0.4 & 219.0 & 1771.7 & 191.7 & 214.2 & 326.0 \\
\hline & & 0.8 & 269.3 & 1783.0 & 147.0 & 194.8 & 358.5 \\
\hline & \multirow{2}{*}{0.9} & 0.4 & 297.7 & 1693.2 & 160.0 & 190.5 & 378.8 \\
\hline & & 0.8 & 287.3 & 1847.2 & 171.2 & 207.8 & 406.3 \\
\hline \multicolumn{3}{|l|}{ Mean (A) } & 229.7 & 1736.4 & 174.7 & 188.0 & 371.2 \\
\hline \multirow{8}{*}{ Wala } & \multirow{2}{*}{0.2} & 0.4 & 223.0 & 1547.0 & 159.7 & 207.2 & 375.0 \\
\hline & & 0.8 & 203.7 & 1457.5 & 122.3 & 191.0 & 380.2 \\
\hline & \multirow{2}{*}{0.4} & 0.4 & 182.2 & 1493.2 & 166.5 & 185.0 & 352.3 \\
\hline & & 0.8 & 210.2 & 1607.8 & 228.5 & 212.5 & 402.7 \\
\hline & \multirow{2}{*}{0.6} & 0.4 & 218.8 & 1571.7 & 239.3 & 225.3 & 348.8 \\
\hline & & 0.8 & 220.8 & 1741.5 & 195.5 & 227.8 & 392.8 \\
\hline & \multirow{2}{*}{0.9} & 0.4 & 211.2 & 2010.5 & 222.8 & 209.5 & 401.2 \\
\hline & & 0.8 & 220.0 & 1860.7 & 236.2 & 220.5 & 399.7 \\
\hline \multicolumn{3}{|l|}{ Mean (A) } & 211.2 & 1662.5 & 196.4 & 232.8 & 381.6 \\
\hline \multirow{8}{*}{ Green } & \multirow{2}{*}{0.2} & 0.4 & 178.0 & 1368.5 & 161.7 & 210.8 & 347.8 \\
\hline & & 0.8 & 206.0 & 1419.3 & 199.5 & 207.0 & 410.0 \\
\hline & \multirow{2}{*}{0.4} & 0.4 & 209.5 & 1576.2 & 222.0 & 225.8 & 365.3 \\
\hline & & 0.8 & 224.3 & 1586.3 & 234.5 & 273.8 & 438.7 \\
\hline & \multirow{2}{*}{0.6} & 0.4 & 224.8 & 1406.5 & 205.8 & 241.7 & 361.5 \\
\hline & & 0.8 & 193.5 & 1464.3 & 192.3 & 244.2 & 379.8 \\
\hline & \multirow{2}{*}{0.9} & 0.4 & 173.0 & 1416.3 & 155.2 & 246.7 & 322.7 \\
\hline & & 0.8 & 187.2 & 1386.7 & 161.5 & 212.5 & 401.3 \\
\hline \multicolumn{3}{|l|}{ Mean (A) } & 199.5 & 1453.0 & 191.6 & 232.8 & 378.4 \\
\hline \multirow{4}{*}{ Nean (B) } & 0.2 & & 192.9 & 1559.6 & 170.6 & 193.1 & 379.9 \\
\hline & 0.4 & & 207.3 & 1582.4 & 199.8 & 210.5 & 382.1 \\
\hline & 0.6 & & 224.4 & 1623.1 & 195.3 & 222.7 & 361.3 \\
\hline & 0.9 & & 229.4 & 1704.1 & 184.5 & 214.6 & 385.0 \\
\hline \multirow{2}{*}{ Mean (C) } & 0.4 & & 205.4 & 1616.6 & 188.5 & 208.5 & 355.1 \\
\hline & 0.8 & & 221.5 & 1618.0 & 186.6 & 211.9 & 399.0 \\
\hline \multicolumn{3}{|l|}{ Mean } & 213.5 & 1617.3 & 187.5 & 210.2 & 377.1 \\
\hline \multicolumn{3}{|l|}{$\begin{array}{l}\mathrm{LSD}_{0.05} \\
\mathrm{~A}\end{array}$} & $\begin{array}{l}\text { n. s. } \\
\text { n. s. } \\
\text { n. s. }\end{array}$ & $\begin{array}{c}256.5 \\
\text { n. s. } \\
\text { n. s. }\end{array}$ & $\begin{array}{l}\text { n. s. } \\
\text { n. s. } \\
\text { n. s. }\end{array}$ & $\begin{array}{l}\text { n. s. } \\
\text { n. s. } \\
\text { n. s. }\end{array}$ & $\begin{array}{l}\text { n. s. } \\
\text { n. s. } \\
37.9\end{array}$ \\
\hline
\end{tabular}

n.s. - not significance 


\section{CONCLUSIONS}

The analyzed basil herbage proved to be a good source of phosphorus, calcium, chlorine and sulphur; the content was generally significantly affected by a cultivar, nitrogen rate and potassium rate, but a greater effect should be attributed to the cultivar-specific traits seemed to have produced a stronger effect than the nitrogen rate or potassium rate. The increasing rate of nitrogen caused an increase in the concentration of the mineral nutrients in the basil herbage. The concentration of magnesium in the basil herbage dry matter was not dependent on a cultivar and nitrogen rate, but it increased under the influence of the increasing amount of potassium applied. On the other hand, the increased amounts of potassium did not modify the share of phosphorus and sulphur in the investigated plant material. Thus, by using adequate amounts of nitrogen and potassium in the nutrition of basil plants, the content of phosphorus, calcium, magnesium, chlorine and sulphur in the herbage can be effectively increased, thereby enriching the chemical composition of raw material.

\section{REFERENCES}

Abduelrahman A.H.N., Elhussein S.A., Osman N.AL., Nour A.H. 2009. Morphological variability and chemical composition of essential oils from nineteen varieties of basil (Ocimum basilicum L.) growing in Sudan. Int. J. Chem. Technol., 1(1): 1-10.

Ali MD.A., Hossain M.A., Mondal MD.F., Farooque A.M. 2003. Effect of nitrogen and potassium on yield and quality of carrot. Pak. J. Biol. Sci., 6(18): 1574-1577.

Bahmanyar M.A., Soodaee-Mashaee S. 2010. Influences of nitrogen and potassium top dressing on yield and yield components as well as their accumulation in rice (Oryza sativa). J. Biotechnol., 9(18): 2648-2653.

Biesiada A., Коєота E. 2010. The effect of nitrogen fertilization on yielding and chemical composition of radicchio chicory for autumn-harvest cultivation. Acta Sci. Pol. Hort. Cult., 9(4): 85-91.

Biesiada A., Kuś A. 2010. The effect of nitrogen fertilization and irrigation on yielding and nutritional status of sweet basil (Ocimum basilicum L.). Acta Sci. Pol. Hort. Cul., 9(2): 3-12.

Chen B.M., Wang Z.H., Li S.X., Wang G.X., Song H.X., Wang X.N. 2004. Effects of nitrate supply on plant growth, nitrate accumulation, metabolic concentration and nitrate reductase activity in three leafy vegetables. Plant Sci., 167: 635-643.

DzIDA K. 2004. The effect of N-K nutrition on the yielding of leaf beet (Beta vulgaris var. cicla) and nutrients content in growing substrate]. Rocz. AR Pozn. CCCLVI, Ogrodnictwo, 37: 55-60. (in Polish)

DzIDA K. 2010. Nutrients contents in sweet basil (Ocimum basilicum L.) herb depending on calcium carbonate dose and cultivar. Acta Sci. Pol. Hort, Cult., 9(4): 143-151.

Dzida K., Pitura K. 2008. The influence of varied nitrogen fertilization on yield and chemical composition of swiss chard (Beta vulgaris var. cicla. Acta Sci. Pol. Hort. Cult., 7 (3): 15-24.

Esmaili E., Kapourchal S.A., Malakouti M.J., Homaee M. 2008. Interactive effect of salinity and two nitrogen fertilizers on growth and composition of sorghum. Plant Soil Environ., 54(12): 537-546. 
FRIEDRICH M. (ed.) 2002. Mineral nutrients in human and animal nutrition. Wyd. AR Szczecin. (in Polish)

GeEtha A., Rao P.V., Reddy D.V. Shaik M. 2009. Effect of organic and inorganic fertilizers on macro and micro nutrient uptake, oil content, quality and herbage yield in sweet basil (Ocimum basilicum). Res. Crops, 10(3): 740-742.

Golcz A., Kujawski P., Markiewicz B. 2008. Effect of nitrogen and potassium fertilization on the nutritional status of hot pepper (Capsicum annuum L.) plants and on substrate salinity. Acta Sci. Pol., Hort. Cult., 7(1): 45-52.

Hanafy Ahmed A.H., Khalil M.K., Farrag Amal M. 2000. Nitrate accumulation, growth, yield and chemical composition of rocket (Eruca vesicaria subsp. sativa) plants as affected by NPK fertilization, kinetin and salicylic acid. ICEHM Cairo Univ., Egypt, 495-508.

KHALID KH.A. 2006. Influence of water stress on growth, essential oil, and chemical composition of herbs (Ocimum sp.). Int. Agrophys., 20: 289-296.

KŁosiewicz-Latoszen L. 1993. Magnesium deficit versus cardiac diseases. Żyw. Człow. Metab., 20(4): 374-380. (in Polish)

Labra M., Miele M., Ledda B., Grassi F., Mazzei M., Sala F. 2004. Morphological characterization, Essentials oil composition and DNA genotyping of Ocimum basilicum L. cultivars. Plant Sci., 167: 725-731.

Markiewicz B., Golcz A., Kleiber T., Bosiacki M. 2011. Effect of nitrogen, phosphorus and potassium fertilization on the content of macroelements in fruits of aubergine (Solanum melongena L.) grown on organic substrates. J. Elementol., 16(1): 69-74.

Michąojć Z. 2000. Effect of nitrogen and potassium fertilization on yield and chemical composition of lettuce, radish and spinach. Rozpr. Nauk. AR Lublin. (in Polish)

Nowacki E. (ed.). 1980. Nitrogen management of crops. PWRiL, Warszawa. (in Polish)

NURZYŃSKA-WIERDAK R. 2006. The yield and chemical components of rocket and kohlrabi leaves in dependence on nitrogen and potassium fertilization. Rozpr. Nauk. AR Lublin. (in Polish)

NURZYŃSKA-WIERDAK R. 2007. Evaluation of morphological and developmental variability and essential oil composition of selected basil cultivars. Herba Pol., 53(93): 255-261.

NURZYŃSKA-WiERDAK R. 2009. Growth and yield of garden rocket (Eruca sativa Mill.) affected by nitrogen and potassium fertilization. Acta Sci. Pol. Hort. Cult., 8(4): 23-33.

NurzyŃsKa-Wierdak R., Borowski B., Dzida K. 2011. Yield and chemical composition of basil herb depending on cultivar and foliar feeding with nitrogen. Acta Sci. Pol. Hort. Cult., 10(1): 207-219.

NurzyŃSKa-Wierdak R., Borowski B. 2011. Dynamics of sweet basil (Ocimum basilicum L.) growth affected by cultivar and foliar feeding with nitrogen. Acta Sci. Pol. Hort. Cult., 10(3): 307-317.

NuRZyŃSKA-Wierdak R., RożeK E., Borowski B. 2011. Response of different basil cultivars to nitrogen and potassium fertilization: total and mineral nitrogen content in herb. Acta Sci. Pol., Hort. Cult., 10(4): 217-232.

NurzyŃska-Wierdak R., Rożek E., Borowski B., Dzida K. 2012. Growth response to nitrogen and potassium fertilization of sweet basil (Ocimum basilicum L.) plants. Acta Sci. Pol. Hort. Cult., 11 (in press).

ÖZCAN M. 2004. Mineral contents of some plants used as condiments in Turkey. Food Chem., 84: 437-440.

ÖZCan M., Arslan D., Unver A. 2005. Effect of drying methods on the mineral content of basil (Ocimum basilicum L.). J. Food Engin., 69: 375-379.

Özcan M., Akbulut M. 2007. Estimation of minerals, nitrate and nitrite contents of medicinal and aromatic plants used as species, condiments and herbal tea. Food Chem., 106: 852-858. 
Rao E.V.P., Puttana K., Ganesha Rao R.S., Ramesh S. 2007. Nitrogen and potassium nutrition of French basil (Ocimum basilicum Linn.). J. Spices Aromat. Plants, 16(2): 99- 105.

Seidler-Łozykowska K., Mordalski R., Kucharski W., Golcz A., Kozik E., WóJcik J. 2009. Economic and qualitative value of the raw material of chosen species of medicinal plants from organic forming. Part II. Yield and quality of sweet basil herb (Ocimum basilicum L.). Acta Sci. Pol. Agric., 8(3): 29-35.

Shehu H.E., Kwari J.D., Sandabe M.K. 2010. Effects of $N, P$ and $K$ fertilizers on yield, content and uptake of N, $P$ and $K$ by sesame (Sesamus indicum). Int. J. Agric. Biol., 12(6), 845-850.

Sifola M.I., Barbieri G. 2006. Growth, yield and essentials oil content of three cultivars of basil grown under different levels of nitrogen in the field. Sci. Hort., 108: 408-413.

Svecova E., Neugebauerova J. 2010. A study of 34 cultivars of basil Ocimum L. and their morphological, economic and biochemical characteristics, using standardized descriptors. Acta Univ. Sapientiae Alimentaria, 3: 118-135.

Zheljazkov V.D., Cantrell Ch.L., Ebelhar M.W., Rowe D.E., CoKer Ch. 2008. Productivity, oil content, and oil composition of sweet basil as a function of nitrogen and sulfur fertilization. Hort. Sci., 43 (5): 1415-1422.

Yамамото А., ТАKano T. 1996. Effects of anion variations in a nutrient solution on the basil growth, essential oil content and composition. Sci. Rept., Fac. Agr., Meijo Univ., 32: 47-52. 